\title{
PCR detection assay for sex determination in papaya using SCAR marker
}

\author{
Kanupriya Chaturvedi ${ }^{1}$, Padmakar Bommisetty ${ }^{1}$, Arpita Pattanaik ${ }^{1}$, \\ Vasugi Chinnaiyan ${ }^{2}$, Dinesh M. Ramachandra ${ }^{2}$, Aswath Chennareddy ${ }^{1 *}$ \\ ${ }^{1}$ Division of Biotechnology, Indian Institute of Horticultural Research, \\ Hesaraghatta Lake Post, Hesaraghatta, Bangalore 560 089, India. \\ ${ }^{2}$ Division of Fruit Crops, Indian Institute of Horticultural Research, Hesaraghatta, \\ Bangalore, India
}

\begin{abstract}
Papaya (Carica papaya L., $2 \mathrm{n}=18$ ), a polygamous angiosperm, is a major fruit crop in tropical and subtropical regions. It is trioecious with three sex forms: male, female, and hermaphrodite, where sex determination is controlled by the XY chromosome pair with two slightly different $\mathrm{Y}$ chromosomes i.e. $\mathrm{Y}$ for male and $\mathrm{Y}^{\mathrm{h}}$ for hermaphrodite. Sex type determination in papaya, which cannot be determined either by embryo shape or morphology at the juvenile developmental stage, is an essential pre-requisite for crop improvement processes as it helps in identification of fruitful plants. Hence, molecular profiling could be used as an alternative that provides a quick and reliable identification of sex types in plantlets at initial stages only. In the present study we have validated the sexlinked sequence characterized amplified region (SCAR) marker W11 using PCR detection assay among different cultivars of papaya i.e. dioecious with either female or male and gynodioecious with either female or hermaphrodites and also performed a double-blind test for validating the seedlings of $84 \mathrm{~F} 1$ plants, which resulted in their sex determination. The assay clearly gives $800 \mathrm{bp}$ band in male plants in dioecious types and hermaphrodite in gynodioecious plants.
\end{abstract}

Keywords: Carica papaya, dioecious, double-blind test, gynodieocious, papaya, SCAR marker, sex determination

\section{Introduction}

Carica papaya L., a native of Latin America, is a diploid $(2 \mathrm{n}=18)$ belonging to the family Caricaceae. Papaya is one of the most important fruit crops of India with a production of 4.71 million tons grown over an area of 0.1 million ha (National Horticulture Board 2012). It is widely grown in many other countries also (Tab.1). Papaya is widely cultivated

* Corresponding author, e-mail: aswathiihr@gmail.com 
Chaturvedi K., Bommisetty P., Pattanaik A., Chinnaiyan V., Ramachandra D. M., Chennareddy A.

Tab. 1. Global papaya production in million tons (source: National Horticulture Board 2012).

\begin{tabular}{lccccccccc}
\hline Countries & 2002 & 2003 & 2004 & 2005 & 2006 & 2007 & 2008 & 2009 & 2010 \\
\hline India & 2.15 & 1.69 & 2.54 & 2.14 & 2.48 & 2.91 & 3.63 & 3.91 & 4.71 \\
Brazil & 1.60 & 1.71 & 1.61 & 1.57 & 1.90 & 1.81 & 1.89 & 1.79 & 1.87 \\
Indonesia & 0.61 & 0.63 & 0.73 & 0.55 & 0.64 & 0.62 & 0.72 & 0.77 & 0.70 \\
Nigeria & 0.76 & 0.80 & 0.86 & 0.76 & 0.76 & 0.77 & 0.69 & 0.76 & 0.70 \\
Mexico & 0.88 & 0.96 & 0.79 & 0.71 & 0.80 & 0.92 & 0.64 & 0.71 & 0.62 \\
Ethiopia & 0.23 & 0.23 & 0.26 & 0.30 & 0.26 & 0.23 & 0.25 & 0.26 & 0.23 \\
Democratic Republic & 0.21 & 0.21 & 0.21 & 0.22 & 0.22 & 0.22 & 0.22 & 0.22 & 0.23 \\
of the Congo & & & & & & & & & \\
Colombia & 0.09 & 0.09 & 0.10 & 0.14 & 0.16 & 0.22 & 0.21 & 0.19 & 0.26 \\
Thailand & 0.35 & 0.31 & 0.28 & 0.03 & 0.13 & 0.20 & 0.20 & 0.21 & 0.21 \\
Guatemala & 0.05 & 0.07 & 0.08 & 0.10 & 0.11 & 0.18 & 0.19 & 0.20 & 0.20 \\
Other & 1.41 & 1.46 & 1.39 & 1.49 & 1.43 & 1.37 & 1.41 & 1.44 & 1.49 \\
\hline TOTAL & 8.32 & 8.17 & 8.85 & 8.01 & 8.90 & 9.45 & 10.05 & 10.46 & 11.22 \\
\hline
\end{tabular}

for its edible fruits and milky latex that yields papain, a proteolytic enzyme, and carpain alkaloids that are of great economic importance. As the yields and proteolytic activity of the crude papain obtained from the female fruits are greater than that obtained from hermaphrodites (MADRIGAL et al. 1980), dioecious papaya cultivars are preferred for the extraction of papain.

The papaya is polygamous plant species with three main sex types, namely pistillate or female, staminate or male, and hermaphrodite (STOREY 1941). The results of earlier reports (Hofmeyr 1938, Storey 1938, 1941, 1953) on the genetic analysis of sex determination in papaya suggest that sex determination is controlled by three alleles. The genetics of sex is very intriguing in the papaya. Among several hypotheses, the genetic balance hypothesis explaining sex determination in papaya (where factors determining femaleness are present in the sex chromosome and that of maleness in the sum total of autosomes) has been widely accepted (HOFMEYR 1938). It is further assumed that $M_{1}$ and $M_{2}$ respectively represent the inert segments of sex chromosomes. The $M_{1}$ is slightly larger than the $M_{2}$ segment. It is presumed that genes responsible for life are eliminated in these inactive regions and cause the lethality of the genotypes $M_{1} M_{1}, M_{1} M_{2}$, and $M_{2} M_{2}$. However, the genotypes $M_{1} m$ and $\mathrm{M}_{2} \mathrm{~m}$ will be viable due to the presence of an active sex chromosome.

Recent reports have proven that sex determination in papaya is controlled by a recently evolved XY chromosome pair, with two slightly different Y chromosomes controlling the development of males (Y) and hermaphrodites ( $\mathrm{Y}^{\mathrm{h}}$ ) (Gschwend et al. 2011, NA et al. 2012, WANG et al. 2012). Traditionally, the propagation of papaya plants is through seeds, which would give rise to a population of generally 1:3 for male to female. However, the sex of these plants cannot be deduced from the external morphology of embryonic or juvenile forms. The sex of the seedlings can be detected only after the plants attain reproductive maturity, i.e. after 5-8 months. However, if the sex of the dioecious plants is identified at the seedling stage, prior to their transplantation to the field, then a desired ratio of male to female plants ( $5 \%$ males $/ 95 \%$ females) can be achieved, thereby saving on the input cost. In 
the case of gynodieocious types, the hermaphrodite plants give pyriform fruits and the female round fruits. However, from the marketing point of view, pyriform fruits are desirable. As the segregation in this case is also 1:1 for female to hermaphrodite, identification at the early stage is desirable.

Molecular markers have been studied earlier for sex determination in papaya (SonduR et al. 1996, Somsri et al. 1998, PARASNis et al. 1999, 2000, Niroshini et al. 2000, 2008, UraSAKI et al. 2002a, b, DePUTY et al. 2002, Lemos et al. 2002). Recently a transcriptomics study has been conducted for sex determination in papaya (URASAKI et al. 2012). However, none of these studies validated the use of sequence characterized amplified region (SCAR) markers across a large population of dioecious and gynodieocious cultivars and a population with an intergeneric cross.

In this paper the SCAR marker W11 (DEPUTY et al. 2002) was initially tested among dioecious and gynodieoecious cultivars and was later used to determine the sex of 84 seedlings of an intergeneric cross of Carica papaya $\times$ Vasconcella cauliflora containing a mixture of male, female and hermaphrodite plants.

\section{Materials and methods}

A total of 98 papaya plants of which a known set of 14 cultivars comprising 6 dioecious and 8 gynodieocious plants (Tab. 2) and unknown set of $84 \mathrm{~F} 1$ seedlings of Carica papaya $\times$ Vasconcella cauliflora maintained at the Indian Institute of Horticultural Research in Bangalore were taken for the study. In the unknown set all the seedlings were marked to confirm SCAR marker results when the seedlings produced their first flower. Healthy and mature leaf tissue ( $2 \mathrm{~g}$ ) was ground in liquid nitrogen until it formed a very fine powder, and genomic DNA was extracted by using modified CTAB (hexadecyltrimethylammonium bromide) method (Doyle and Doyle, 1990). Purified DNA was quantified using GeneQuant UV-spectrophotometer (GE Health Care Bio-sciences Ltd, U.K.) and diluted accordingly for further analysis.

Tab. 2. List of dioecious and gynodioecious papaya (Carica papaya L.) varieties used for validation.

\begin{tabular}{lcl}
\hline Type & Sample number & Name of the variety and sex type \\
\hline & 1 & Line 21 Male \\
2 & Line 21 Female \\
3 & Shilong Male \\
Dioecious & 4 & Shilong Female \\
5 & Nigeria Male \\
6 & Nigeria Female \\
\hline & 7 & Arka Prabhat Female \\
& 9 & Arka Prabhat Hermaphrodite \\
Gynodioecious & 10 & Surya Hermaphrodite \\
& 11 & Surya Female \\
12 & Thailand Hermaphrodite \\
13 & Thailand Female \\
14 & Dwarf Lilly Female \\
& & Dwarf Lilly Hermaphrodite \\
\hline
\end{tabular}


PCR amplification profile was carried out in $25 \mu \mathrm{L}$ volume containing $10 \mathrm{mM}$ Tris- $\mathrm{HCl}$, $\mathrm{pH} 8.3,1.5 \mathrm{mM} \mathrm{MgCl}_{2}, 50 \mathrm{mM} \mathrm{KCl}, 0.2 \mathrm{mM}$ each dNTP, $0.5 \mu \mathrm{M}$ each primer, $50 \mathrm{ng}$ genomic DNA and 0.6 units of TaqDNA polymerase (Bangalore Genei, Bangalore). Reactions were carried out in an Eppendorf mastercycler gradient thermocycler (Eppendorf, Hamburg, Germany) using the following temperature profile: an initial step of $5 \mathrm{~min}$ at $95^{\circ} \mathrm{C}, 30 \mathrm{cy}-$ cles of $1 \mathrm{~min}$ at $95^{\circ} \mathrm{C}, 1 \mathrm{~min}$ at $58.5^{\circ} \mathrm{C}$ and $1 \mathrm{~min}$ at $72{ }^{\circ} \mathrm{C}$, and a final step of $7 \mathrm{~min}$ at 72 ${ }^{\circ} \mathrm{C}$. Amplification products were screened by electrophoresis using $1.5 \%$ agarose gel.

\section{Results}

Diverse dioecious and gynodioecious papaya cultivars were initially screened for linkage of W11 to sex type. The reaction profile of this SCAR marker assay was optimized by modifying the earlier mentioned protocol (DEPUTY et al. 2002) through a change of the concentrations of PCR ingredients, such as a decrease in $\mathrm{MgCl}_{2}$ concentration, an increase in the concentration of dNTPs, primers, DNA and Taq polymerase. Amplified fragment of 800 bp were obtained in hermaphrodite and male papaya plants only, but not in female plants. This amplification pattern was confirmed by initial screening and validated in true male, female and hermaphrodite plants of both dioecious and gynodioecious cultivars of Carica papaya and Visconcella cauliflora (Fig. $1 \mathrm{a}, \mathrm{b}$ ), which were used as controls for later validation assay.

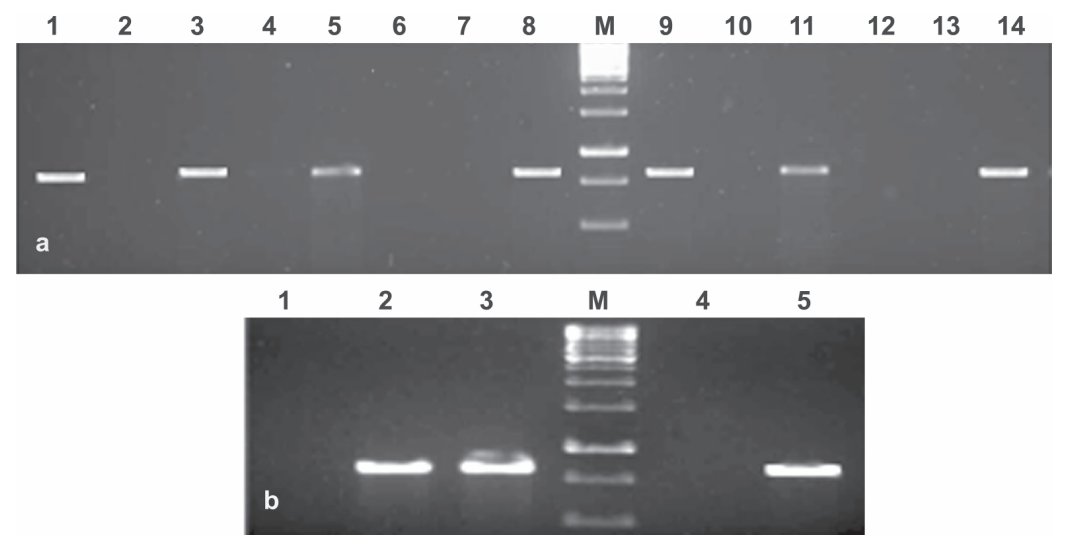

Fig. 1. Amplification pattern of W11 marker among male, female and hermaphrodite specimens of dioecious and gynodioecious papaya plants.W11 scar marker giving an amplicon of $800 \mathrm{bp}$ size only in male and hermaphrodite, but not in female plants; $\mathrm{M}-1 \mathrm{~kb}$ ladder; a) from 1 to14: male, female and hermaphrodite papaya cultivars (refer to table 2 for details); b) 1 'Surya' (female), 2 - 'Shillong' (male), 3 - 'Surya' (hermaphrodite), 4 - V. cauliflora (female), 5 - V. cauliflora (male).

We used 84 F1 two month old seedling plants of an intergeneric cross of Carica papaya $\times$ Visconcella cauliflora, information about the sex of which was unknown, for validation purpose. Genomic DNA was extracted from tender and healthy leaves of 10 day old leaves. These seedlings were maintained until adult stage and used for cross-verification in the field. Of 84 papaya seedlings, a screened amplified 800 bp fragment was obtained in only three 
plants (results not shown) indicating that they might be either hermaphrodite or male, while those lacking $800 \mathrm{bp}$ fragment were considered to be females. The analysis was repeated three times, confirming the reproducibility of results. Internal controls were used during each step of the analysis. After flowering we observed that the plants that showed the band and were tagged were all hermaphrodites and rest were females.

\section{Discussion}

Prior information about the sex type in papaya is necessary before an elite breeding program is planned. From studies on controlled pollinations over years (SINGH 1990), it was established that in the progenies of a cross whose parents are known (pure line), the proportion of males and bisexual or female follows a definite ratio. In the dioecious types, if flowers of female plants are pollinated with the flower of male plants the progenies obtained will have approximately 50\% males and 50\% females. In the gynodioecious types where either bisexual plants are selfed or the female is cross pollinated by bisexual flowers, the progenies obtained will be 50\% females and 50\% hermaphrodites. The gynodioecious types are better in fruit production as both female and hermaphrodite plants produce fruits, while in dioecious types only female plants produces fruits.

Previous studies have provided preliminary data indicating that random amplified polymorphic DNA (RAPD) markers might be useful for detecting sex expression in papaya (Sondur et al. 1996, Somsri et al. 1998, Niroshini et al. 2000, 2008, PArasnis et al. 2000, Lemos et al. 2002, UrASAKI et al. 2002a, b), but these reports utilized a relatively small number of plants. However, DePUTY et al. (2002) reported SCAR markers that are specific for male and hermaphrodite plants in a large number of plants. DepuTy et al. (2002) cloned three RAPD-PCR products showing linkage to the gene that determines flower sex, Sex1, in papaya. Two of these RAPD products, T12 and T1, had been previously mapped to $7 \mathrm{cM}$ flanking the Sex1 gene. The third product W11, which we validated, was chosen because W11 is closer to Sex 1 than either T12 or T1. SCAR W11 and SCAR T12 were mapped in a papaya 'Sun-Up' and 'Kapoho' cross. Both of these cultivars are of the Hawaiian type. All Hawaiian types have previously been shown to be quite similar at the DNA level (STILES et al.1993). SCAR W11 and SCAR T12 showed linkage in all 182 plants, indicating these markers are within $0.3 \mathrm{cM}$ of Sex1. There were no crossovers between SCAR T12 and Sex 1 in the 182 plants, indicating a linkage significantly closer than the $7.0 \mathrm{cM}$ previously reported by SonDUR et al. (1996).

SCAR W11 produced products almost exclusively in males and hermaphrodites but not in females; however, it is not clear at this time whether the difference is the result of a limited number of base changes in the SCAR binding sites or more substantial alterations such as deletions of the binding sites or even the entire regions. In the present study the W11 SCAR marker validated in the cultivars of Carica papaya and Visconcella cauliflora, amplified a discriminating band in hermaphrodites and male papaya plants, but not in females, (Figs. $1 \mathrm{a}, \mathrm{b}$ ). The reason may be that the specific chromosomal region for sex type determination in papaya shares an identical segment of the $Y$ chromosome of males and hermaphrodite plants and is absent in females. This result is consistent with the expected result and as reported by DepuTy et al. (2002). Liu et al. (2004) identified the male specific (MSY) region in hermaphrodite and male papaya plants and found that some sequences of this region 
are common in both male and hermaphrodite plants. In our studies the fragments of $800 \mathrm{bp}$ shared identical sequences between male and hermaphrodite type papaya, and this may support the above study (data not shown).

Detection of sex linked RAPD markers as well as the SCAR markers have been attempted in several dioecious species. Thirty two male-specific RAPD bands were identified in hop (Humulus lupulus L.) by the screening of 900 random primers (POLLEY et al. 1997). Others found one RAPD fragment of $400 \mathrm{bp}$ size, closely linked with the male sex type of hemp (Cannabis sativa L.) (MANDOLINo et al. 1999). The pointed gourd (Trichosanthes dioica Roxb.) has also been studied and found to have a RAPD marker associated with females that is absent in all male plants (SINGH et al. 2002). Similarly, the presence of a female-specific band in nutmeg (Myristica fragrans Houtt.) has also been reported by the screening of 60 operon primers (SHIBU et al. 2000). Others have detected two RAPD markers linked to M locus (maleness) in asparagus (Asparagus officinalis L.) and successfully converted one of these bands to a SCAR marker (JIANG and SINK 1997).

The results illustrate the possibility of developing a molecular marker based method to identify sex at seedling stage in other agriculturally important dioecious plants including nutmeg (M. fragrans Houtt.), hemp (C. sativa L.), pistachio (Pistacia vera $\mathrm{L}$.), kiwifruit (Actinidia chinensis P.), asparagus (A. officinalis L.). Farming of these crops could greatly benefit from the development of methods for sex detection at an early stage as a sufficiently larger number of productive hermaphrodite or female (depending on the market preference) plants could be cultivated by minimizing the number of unproductive male trees.

In our study the assay kit has been successfully used to identify the hermaphrodite plants in the segregating population $\left(\mathrm{F}_{1}\right)$ of Carica papaya $\times$ Vasconcellea cauliflora, which was developed for papaya ring spot virus (PRSV) resistance. The results of this molecular based detection of sex type in papaya were in congruent with the morphological observations among $84 \mathrm{~F} 1$ papaya plants. The three plants that showed an amplification of the 800 bp fragment turned out to be hermaphrodites while the remaining 81 plants were females. Thus the present assay clearly identified the true sex type in the seedling stage of the papaya plants. This assay is more like a double blind test where the plants were marked before flowering as per our test and validated once the flowering occurred. It saved time and also increased the confidence level of the marker.

This can go a long way in reducing the period taken for developing resistant lines for PRSV. In the intergeneric hybridization, the female parent used was gynodioecious Carica papaya and the male was the dioecious type Vasconcellea cauliflora. The sex of the segregants if identified in the $F_{1}$ or in $F_{2}$ generation after screening would help in reducing the population size for further sib mating, which would be easily manageable.

\section{References}

Deputy, J. C., Ming, R., Ma, H., Liu, Z., Fitch, M. M. M., Wang, M., Manshardt, R., StiLES, J. I., 2002: Molecular markers for sex determination in papaya (Carica papaya L.). Theoretical and Applied Genetics 106, 107-111.

Doyle, J. J., Doyle, J. L., 1990: Isolation of plant DNA from fresh tissue. Focus 12, 13-15. 
Gschwend, A. R., Qingyi, Y., Eric, J. T., Fan-Chang, Z., Han, J., Vanburen, R., Aryal, R., Charlesworth, D., Moore, P. H., Paterson, A. H., 2012: Rapid divergence and expansion of the X chromosome in papaya. Proceedings of the National Academy of Sciences of the United States of America 109, 13716-13721.

Hofmeyr, J. D. J., 1938: Genetical studies of Carica papaya L. South African Journal of Science 35, 300-304.

JIANG, C., Sink, K. C., 1997: RAPD and SCAR markers linked to the sex expression locus $\mathrm{M}$ in asparagus. Euphytica 94, 329-333.

Lemos, M. E. G., Silva, P. C. L. S., Zaidan, A. H., 2002: Identification of sex in Carica papaya L. using RAPD markers. Euphytica 127, 179-184.

Liu, Z., Moore, P. H., Ma, H., Ackerman, C. M., Ragiba, M., Yu, Q., Pearl, H. M., Kim, M. S., Charlton, J. W., Stiles, J. I., Zee, F. T., Patterson, A. H., Ming, R., 2004: A primitive $\mathrm{Y}$ chromosome in papaya marks incipient sex chromosome evolution. Nature 427, 348-352.

Madrigal, L. S., Ortiz, A. N., Cooke, R. D., Fernandez, R. H., 1980: The dependence of crude papain yields on different collection ('tapping') procedures for papaya latex. Journal of the Science of Food and Agriculture 31, 279-285.

Mandolino, G., Carboni, A., Forapani, S., Faeti, V., Ranalli, P., 1999: Identification of DNA markers linked to the male sex in dioecious hemp (Cannabis sativa L.). Theoretical and Applied Genetics 98, 86-92.

Na, J-K., Wang, J., Murray, J. E., Gschwend, A. R., Wenli, Z., Yu, Q., Navajas-Pérez, R., Feltus, A., Chen, C., Kubat, Z., Moore, P. H., Jiang, J., Paterson, A. H., Ray Ming, R., 2012: Construction of physical maps for the sex-specific regions of papaya sex chromosomes. BMC Genomics 13,176-181.

National Horticulture Board, 2012: Area and production statistics. Retrieved April 29, 2013 from http://nhb.gov.in/area\%20_production.html

Niroshini, E., Everard, J. M. D. T., Karunanayake, E. H., Tirimanne, T. L. S., 2000: Sex specific random amplified DNA (RAPD) markers in Carica papaya L. Tropical Agricultural Research 12, 41-49.

Niroshini, E., Everard, J. M. D. T., Karunanayake, E. H., Tirimanne, T. L. S., 2008: Detection of sequence characterized amplified region (SCAR) markers linked to sex expression in Carica papaya L. Journal of the National Science Foundation of Sri Lanka 36, $145-150$.

Parasnis, A. S., Ramakrishna, W., Chowdari, K. V., Gupta, V. S., Ranjekar, P. K., 1999: Microsatellite (GATA) $n$ reveals sex-specific differences in papaya. Theoretical and Applied Genetics 99, 1047-1052.

Parasnis, A. S., Gupta, V. S., Tamhankar, S. A., Ranjekar, P. K., 2000: A highly reliable sex diagnostic PCR assay for mass screening of papaya seedlings. Molecular Breeding 6, 337-344.

Polley, A., Seigner, E., Ganal, M. W., 1997: Identification of sex in hop (Humulus lupulus) using molecular markers. Genome 40, 357-361.

Shibu, M. P., Ravishankar, K. V., Anand, L., Ganesshaiah, K. N., Shankar, U., 2000: Identification of sex-specific DNA markers in the dioecious tree, nutmeg (Myristica fragans Houtt.). Plant Genetic Resources Newsletter 121, 59-61. 
Singh, I. D., 1990: Papaya. Oxford and IBIT Pub., Co. Pvt. Ltd., New Delhi.

Singh, M., Kumar, S., Singh, A.K., Ram, D., Kalloo, G., 2002: Female sex-associated RAPD marker in pointed gourd (Trichosanthes dioica Roxb.). Current Science 82, 131132.

Sondur, S. N., Manshardt, R. M., Stiles, J. I., 1996: A genetic linkage map of papaya based on randomly amplified polymorphic DNA markers. Theoretical and Applied Genetics 93, 547-553.

Somsri, S., Fletcher, R. J., Drew, R., Jobin, M., Lawson, W., Graham, M. W., Drew, R. A., 1998: Developing molecular markers for sex prediction in papaya (Carica papaya L.). Acta Horticulturae 461, 141-148.

Stiles, J. I., Lemme, C., Sondur, S., Morshidi, M. B., Manshardt, R., 1993: Using randomly amplified polymorphic DNA for evaluating relationships among papaya cultivars. Theoretical and Applied Genetics 85, 697-701.

Storey, W. B., 1938: Segregation of sex types in solo papaya and their application to the selection of seed. Proceedings American Society of Horticultural Science 35, 83-85.

Storey, W. B., 1941: The botany and sex relationships of the papaya. HawaiiAgricultural Experiment Station Bulletin 87, 5-22.

Storey, W. B., 1953: Genetics of papaya. Journal of Heredity 44, 70-78.

Urasaki, N., Tarora, K., Uehara, T., Chinen, I., Terauchi, R. Tokumoto, M., 2002a: Rapid and highly reliable sex diagnostic PCR assay for papaya (Carica papaya L.). Breeding Science 52, 333-335.

Urasaki, N., Tokumoto, M., Tarora, K., Ban, Y., Kayano, T., Tanaka, H., Oku, H., Chinen, I., Terauchi, R., 2002b: A male and hermaphrodite specific RAPD marker for papaya (Carica papaya L.). Theoretical and Applied Genetics104, 281-285.

Urasaki, N., Tarora, K., Shudo, A., Ueno, H., Tamaki, M., Miyagi, N., Adaniya, S., MatSUMURA, H., 2012: Digital transcriptome analysis of putative sex-determination genes in papaya (Carica papaya). PLoS ONE 7, e40904.

Wang, J., Na, J-K. Yu, Q., Gschwend, A. R., Han, J., Zeng, F., Aryal, R., VanBuren, R., Murray, J. E., Zhang, W., Navajas-Péreze, R., Feltus, F. A., Lemke, C., Tong, E. J., Chen, C., Wai, C. M., Singh, R., Wang, M-L., Jia Min, X., Alam, M., Charlesworth, D., Moore, P. H., Jiang, J., Paterson, A. H., Ming, R., 2012: Sequencing papaya X and Yh chromosomes reveals molecular basis of incipient sex chromosome evolution. Proceedings of the National Academy of Sciences of the United States of America 109, $13710-13715$. 